Dr DRAGOMIR BONDŽIĆ, viši naučni saradnik

Institut za savremenu istoriju

Beograd, Trg Nikole Pašića 11

UDK 94:[53:005.71(497.1)"1947/..."(093.2)

53:929 Савић П.(093.2)

\title{
RAD PAVLA SAVIĆA U MOSKVI 1944. I 1945/1946. I PROJEKAT ZA IZGRADNJU JUGOSLOVENSKOG INSTITUTA ZA FIZIKU*
}

\begin{abstract}
APSTRAKT: U radu se na osnovu dostupne arhivske grade i relevantne literature rekonstruišu dva boravka jugoslovenskog naučnika, profesora Beogradskog univerziteta komuniste i partizana Pavla Savića u Moskvi, od aprila do oktobra 1944. i od jula 1945. do jeseni 1946. godine. Posebna pažnja je posvećena Savićevom radu na planiranju izgradnje instituta za fiziku u Jugoslaviji i pridobijanju pomoći od sovjetskih naučnika i vlasti za realizaciju tih planova.
\end{abstract}

Ključne reči: Pavle Savić, nauka, institut za fiziku, Sovjetski Savez, Jugoslavija, Josip Broz Tito

U proleće 1944. Pavle Savić (1909-1994), istaknuti srpski naučnik, saradnik Irene Žolio Kiri u Institutu za radijum u Parizu 30-ih godina, profesor Beogradskog univerziteta, partizan, šifrant Vrhovnog štaba NOVJ i većnik, potpredsednik i poverenik za prosvetu AVNOJ-a, ${ }^{1}$ iznenada je unapređen od običnog vojnika u čin majora i postao član Vojne misije NOVJ koja je, preko Barija, severne Afrike, Teherana i Bakua, 2. aprila 1944. stigla u Moskvu. Na čelu misije je formalno bio general Velimir Terzić, ali glavnu reč je imao član Politbiroa CK KPJ i jedan od najbližih Titovih saradnika,

${ }^{*}$ Rad je deo projekta Srpsko društvo u jugoslovenskoj državi u 20. veku: između demokratije i diktature (177016) koji finansira Ministarstvo prosvete, nauke i tehnološkog razvoja Republike Srbije.

${ }^{1}$ O životu i radu Pavla Savića videti: Павле Савић, Наука и gрушишво. Изабрани pagoви. Прилози животойису, прир. Милица Мужијевић, Владимир Дедијер, Београд 1978; Зборник у иасй Павла Савића йовоgом сеgамgесейойоgишњице рођења, ур. Милутин Гарашанин, Београд 1980; Слободан В. Рибникар, Павле Савић (1909-1994), Живот и дело српских научника, Београд 1999, 415-452; Dragomir Bondžić, Pavle Savić - naučnik u ratu, Intelektualci i rat 1939-1947. Zbornik radova s Desničinih susreta 2012, Dio 1, uredili Drago Roksandić, Ivana Cvijović Javorina, Zagreb 2013, 239-249; itd. 
Milovan Đilas. Cilj misije je bio da se organizuje sovjetska pomoć za NOVJ, obezbedi kredit i raspodela strane pomoći i da se ispitaju mogućnosti međunarodnog priznanja revolucionarne vlasti. ${ }^{2}$

Uloga Pavla Savića u ovoj misiji ne može se iz dostupnih izvora potpuno razjasniti. Savić pre toga nikada nije bio u Rusiji, nije znao ruski jezik, nije se bavio vojnim pitanjima niti je bio kompetentan za ostala pitanja kojima se misija bavila. Jedino njegova uloga kao višegodišnjeg šifranta Vrhovnog štaba, bliskog saradnika vrhovnog komandanta Tita i jedine osobe posrednika između Tita i Moskve sve do jula 1943. i partijski staž mogu dati neka objašnjenja zašto se Savić u proleće 1944. našao u Moskvi (mada je od jula 1943. bio u sukobu sa partijskim vođstvom, zbog kojeg je udaljen sa mesta šifranta i drugih dužnosti i uklonjen iz Vrhovnog štaba). Isto tako, renome istaknutog svetskog naučnika koji je Savić imao u partijskim redovima (zahvaljujući radu u Parizu sa Irenom Žolio Kiri pre rata), a istovremeno i pouzdanog komuniste, što je bila retkost, činio ga je dobrim predstavnikom nauke i kulture nove Jugoslavije i osobom za upoznavanje sa naučnom organizacijom i naučnim prilikama i kadrovima $u$, za jugoslovenske komuniste, tada najrazvijenijoj zemlji na svetu.

Savić je u Moskvi u početku radio na pronalaženju dece jugoslovenskih komunista koja su evakuisana iz Moskve krajem 1941. Zatim je bio izabran za potpredsednika Sveslovenskog komiteta i planirano je da početkom septembra 1944. u tom svojstvu putuje u SAD na prvi sveslovenski kongres. Dok je čekao sovjetsku i američku vizu, Vrhovni štab ga je unapredio u čin potpukovnika i odlikovao ga Ordenom partizanske zvezde drugog reda. Dobio je i zadatak da uruči dva ordena narodnog oslobođenja Luju Adamiču i Zlatku Balokoviću za njihovu podršku partizanskom pokretu tokom rata. Planirao je da taj put iskoristi i da upozna američke institute, laboratorije i naučni rad. ${ }^{3}$ Međutim, na kraju nije otišao SAD, kako sam kaže „zbog nesuglasica u Sveslovenskom komitetu“, ali sudeći po depeši

${ }^{2}$ Arhiv Jugoslavije (AJ), Kabinet Maršala Jugoslavije (KMJ), 836, I-3-b/676, depeša Maršalu Titu sa spiskom članova misije, 12. april 1944; AJ, 790/21, Jugoslovenska vojna misija u SSSR (1944/45); Milovan Đilas, Razgovori sa Staljinom, Beograd 1990, 14-16; Владимир Дедијер, Дневник, Београд 1951, 754; Ogноси Јуіославије и Русије (СССР) 1941-

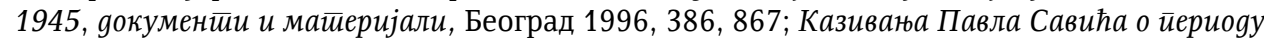
1944-1960. іолине, Београд 1993, 7; Александар В. Милетић, Сйољнойолийичка gелайности Милована Биласа 1944-1953, Југословенска дипломатија 1945-1961, Зборник радова, ур. Слободан Селинић, Београд 2012, 294-298. U delegaciji su bili i pukovnik Velimir Stojnić, pukovnik Mile Pavičić, pukovnik dr Đuro Mešterović, potpukovnici Stanko Danilović, Vinko Švob i Milan Lah, poručnik Bogdan Popović, potporučnik Marko Popović i vajar Antun Augustinčić.

${ }^{3}$ AJ, KMJ, 836, I-3-b/677, Izveštaj vojne misije NOVJ u SSSR, V(elimira) Terzića vrhovnom komandantu NOV i PO, Maršalu Jugoslavije J(osipu) B(rozu) Titu, Moskva, 1. jun 1944; П. Савић, Наука и gрушишво, 259-272; В. Дедијер, н. g., 776. 
koju je Moša Pijade uputio Titu krajem septembra 1946, razlog neodlaska je bio što nije dobijena američka viza. Pijade je javljao: „Amerikanci konačno odbili vizu delegaciji Sveslovenskog komiteta. Zato ni Paja [Pavle Savić] neće onamo ići. Ostaje pitanje kako će se dostaviti ordeni za Ameriku. Paja pita da li da dalje produži rad ili da se vrati u zemlju“. ${ }^{4}$

Iako Savić nije otišao u Ameriku, ciljevi koji su mu postavljani na planiranom putovanju, kao i naučne aktivnosti koje je imao i u Moskvi, sugerišu da su već tada, 1944. godine, u vrhu partijskog rukovodstva postojali izvesni planovi za posleratni naučni razvoj zemlje. Već mesec dana po dolasku u Moskvu Savić je uz dozvolu maršala Tita i sovjetskih vlasti počeo da se bavi naučno-istraživačkim radom i to $u$ Institutu za fizičke probleme Akademije nauka SSSR-a. Tu se upoznao sa akademikom Pjotrom Leonidovičom Kapicom (1894-1984), Aleksandrom J. Šaljnikovim (1905-1986) i drugim naučnicima, što je kasnije imalo značaj za razvoj nauke u Jugoslaviji. Iako je njegov predratni rad sa Irenom Žolio-Kiri na otkriću fisije bio zapažen u međunarodnim okvirima, Savić je u Moskvi promenio oblast i tematiku rada - počeo se baviti problemom ponašanja tečnog helijuma na izuzetno niskim temperaturama. I pored nove teme, nepoznavanja jezika, dugogodišnjeg prekida naučnog rada i iscrpljenosti izazvane ratnim naporima, Savić se i na ovom poslu dobro snašao, pridobio poverenje sovjetskih naučnika i postigao zapažene rezultate. ${ }^{5}$

Može se postaviti i pitanje zašto Savić nije nastavio da se bavi temama na kojima je radio u Parizu krajem 30-ih i postigao rezultate po kojima je bio poznat u nauci. Savić u svojim kazivanjima 1993. pominje da ga je Alihanov (Abram I. Alihanov 1904-1970, sovjetski fizičar, stručnjak za radioaktivnost, konstruktor prvog reaktora u SSSR) tokom boravka u Moskvi pitao da napusti posao sa niskim temperaturama i posveti se svojoj profesiji, atomskoj energiji, pod uslovom da pet godina prekine svaku vezu sa porodicom, zemljom i svim poznanicima. Savić je pristao, pod uslovom da dobije odobrenje „od naših“, tj. od jugoslovenskih vlasti. Odobrenje je dobio, ali mu je kasnije sa sovjetske strane saopšteno da kao stranac ipak ne može učestvovati u predloženom poslu, te je nastavio rad na niskim temperaturama. U radu iz 1999. godine Slobodan Ribnikar pominje da je

${ }^{4}$ AJ, CK SKJ, 507, Međunarodna komisija, SSSR, IX, 119/V-3, Depeša M. Pijade Titu, bez datuma; П. Савић, Наука и gрушйво, 272.

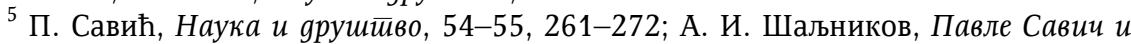

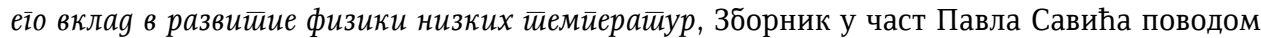
седамдесетогодишњице рођења, ур. Милутин Гарашанин, Београд 1980, 57-61; Казивања Павла Савића о иеериоgу 1944-1960, 7-8; Милош Јевтић, Разі̄овори са Винианиима, Београд 1998, 22 (разговор са П. Савићем вођен маја 1974); Слободан В. Рибникар, Дойринос Павла Савића айомисиичикм наукама, Зборник Филозофског факултета, Београд 1990, 221; С. В. Рибникар, Павле Савић (1909-1994), 421-422. 
Savić „intimno priželjkivao" da ga Sovjeti pozovu da radi na problemima fisije, iako ističe da po povratku iz Pariza i tokom rata nije raspolagao novom literaturom, nije se bavio naukom i do bacanja nuklearne bombe na Hirošimu i Nagasaki avgusta 1945. nije ni slutio da njegov rad sa Irenom Žolio-Kiri može biti upotrebljen u razorne svrhe. Stoga, zaključuje Ribnikar, Savić nije ni mogao biti od koristi Sovjetima koji su u to vreme u najstrožoj tajnosti iza Urala radili na svom nuklearnom oružju, te su mu dali da $\mathrm{u}$ Institutu za fizičke probleme istražuje sasvim drugu temu. ${ }^{6}$

Odgovor na Savićevo pitanje da li da nastavi rad ili da se vrati $\mathrm{u}$ zemlju, postavljeno posle neuspeha da otputuje u SAD, dao je Tito 6 . oktobra 1944. naređujući mu da se vrati (što je i sam Savić priželjkivao, želeći da prisustvuje oslobađanju Beograda). Tako se prvi boravak Pavla Savića u Moskvi završio 15. oktobra 1944. kada je avionom, preko Krajove i Vršca, došao u Beograd u vreme kada je grad oslobađan od nemačke okupacije. $^{7}$

Po dolasku u Beograd Savić je preuzeo niz dužnosti u organima nove države i dao doprinos njihovom stvaranju i radu. Već u novembru 1944. učestvovao je na Antifašističkoj skupštini narodnog oslobođenja Srbije na kojoj je izabran za člana Predsedništva i za poverenika za obnovu Srbije. Kasnije je postao predsednik Privrednog saveta Srbije i izabran je za člana CK KP Srbije. Avgusta 1945. učestvovao je na Trećem zasedanju AVNOJ-a, na kojem je izabran za člana Zakonodavnog odbora i za člana Ustavotvorne skupštine. ${ }^{8}$ Odmah po oslobođenju Beograda, Savić se aktivirao i u obnovi rada Beogradskog univerziteta kao član Komisije za obnovu Univerziteta. Decembra 1944. učestvovao je na svečanoj akademiji studenata i profesora posvećenoj narodnooslobodilačkoj borbi i budućim zadacima Univerziteta. ${ }^{9}$

${ }^{6}$ Казивана Павла Савића о йериogy 1944-1960, 9; С. В. Рибникар, Павле Савић (1909-1994), 421-422. Na osnovu dostupnih izvora i Savićevih zapisa, ne može se ništa preciznije zaključiti ni o Savićevim eventualnim očekivanjima, niti o odnosu sovjetskih nadležnih organa prema Saviću, njegovom ranijem radu i novim naučnim zadacima u Moskvi. Nismo naišli na pouzdane podatke da je Savić u Sovjetskom Savezu uopšte posmatran kao saradnik Irene Žolio Kiri, čija bi saznanja mogla da doprinesu sovjetskim nuklearnim istraživanjima.

${ }^{7}$ AJ, 836, KMJ, I-3-b/701, Depeša J. B. Tita V. Terziću od 6. oktobra 1944. kojom se naređuje da se Savić prvim avionom vrati u zemlju; П. Савић, Наука и gрушйво, 279280; Казивања Павла Савића о иеериоgу 1944-1960, 8-9.

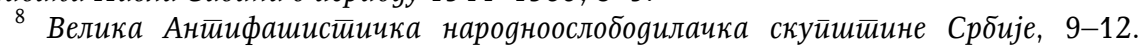
новембар 1944, Београд 1944, 15; Tреће засеgање АВНОJ-а, Засеgање Привремене Нарояне

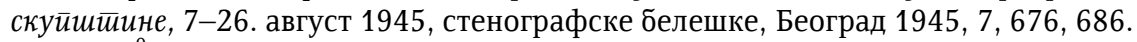

${ }^{9}$ AS, fond Beogradski univerzitet, Komisija za obnovu Univerziteta, Izveštaj komi-

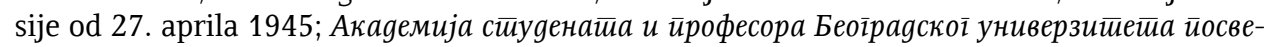
ћена нарояноослобоgилачкој борби, Политика, бр. 11839, 8. децембар 1944, 3. 
Već jula 1945, međutim, Savić je ponovo otišao u Moskvu kao član jugoslovenske delegacije na proslavi 220-godišnjice Akademije nauka SSSR-a. ${ }^{10}$ Sa suprugom i ćerkom ostao je u Moskvi sa namerom da nastavi ranije započeta naučna istraživanja. Boravio je u Sovjetskom Savezu do septembra 1946, nastavljajući rad na tečnom helijumu u Institutu za fizičke probleme, gde je izabran za starijeg naučnog saradnika Akademije nauka. ${ }^{11}$ Međutim, posebnu pažnju je posvetio i obezbeđivanju sredstava, materijalne i kadrovske pomoći za osnivanje Instituta za fiziku u Jugoslaviji. Naravno, u tom poduhvatu je morao imati podršku i podsticaj iz samog vrha državne i partijske vlasti. To se može zaključiti i iz pisama koje su Savić i Kapica poslali Josipu Brozu 13. i 17. marta 1946. sa detaljnim projektom za osnivanje fizičkog instituta sa spiskom potrebnog materijala i kadrova i molbom za pomoć od sovjetskih vlasti.

Savić je na početku pisma izrazio „duboku zahvalnost" Titu za ukazano poverenje i radost što se nalazi na poslu gde najviše može da koristi "narodu i partiji“. „Mislim da tek sad mogu da se opravdam za Tvoje neprestano staranje za mene $u$ toku rata, kada sam se kao nekoristan balast nalazio među drugovima“, pisao je Savić, aludirajući na svoje delovanje tokom rata i nagoveštavajući značaj svoje misije u Sovjetskom Savezu. Istakao je da su se za podizanje „našeg Fizičkog Instituta“ zainteresovali mnogi sovjetski ljudi, „a naročito akademik Kapica“. Sa akademikom Kapicom i njegovim saradnicima izrađen je potpun plan podizanja i opreme takvog Fizičkog instituta „kakav odgovara savremenoj nauci, a po uzoru na ovdašnji Kapicin institut". Savić je izveštavao Tita da je Kapica detaljno pregledao plan izgradnje instituta i spisak materijala i potpuno se složio i smatrao da je predviđena suma od 25 miliona [ne piše u kojoj valuti] potpuno dovoljna, a „možda i premaša iznos". Isticao je, međutim, da je potrebno formalno odobrenje sovjetske vlade kako bi mogla da se naruči izrada traženih mašina.

10 Архив внешней политики Российской Федерации, Фонд 202 (Посольство СССР в Югославии), Опис 2, Папка 102, Дело 1, Л. 6-7 (za ustupanje materijala iz ruskih arhiva izražavamo srdačnu zahvalnost kolegi Momiru Ninkoviću); AJ, 836, KMJ, I, 3-b/615, Pavle Savić u jugoslovenskoj delegaciji u SSSR, 1945; Arhiv SANU, zbirka Aleksandra Belića, AB-14386-IV-3, Pozivnica A. Beliću za proslavu; П. Савић, Наука и gрушйво, 281-283. Pored Savića u delegaciji su bili Aleksandar Belić, predsednik Srpske akademije nauka, Jevrem Nedeljković, profesor Medicinskog fakulteta i član (do aprila 1945. i predsednik) Komisije za obnovu Univerziteta, Siniša Stanković, profesor Filozofskog fakulteta i član Predsedništva AVNOJ-a i Fran Kidrič, predsednik Slovenačke akademije znanosti i umetnosti, dok pisac Vladimir Nazor zbog bolesti nije otputovao.

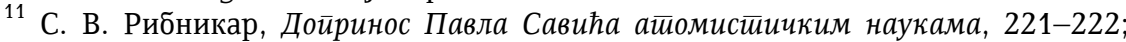
Исти, Павле Савић (1909-1994), 421-422; Казивања Павла Савића о иериоgу 1944-1960, 9. Tokom naučnog rada u Moskvi Savić je sa saradnicima otkrio fenomen „magle“ u oblasti niskih temperatura i novi metod za dobijanje niskih temperatura i rezultate objavio u Moskvi i Beogradu (videti: П. Савић, Наука и gрушйво, 54-59). 
Najbolji put da se do tog odobrenja dođe jeste da maršal Tito napiše pismo drugu Staljinu, a za sve ostalo pobrinuo bi se Kapica, smatrao je Savić. Kapica je o tome razgovarao sa Maljenkovom [Georgije M. Maljenkov] i još nekim članovima CK i zaključio da su oni „više nego raspoloženi da nam pomognu“ i da će „isto tako masa akademika učiniti sve za nas“. Jugoslovenski plan izgradnje instituta dolazi u „pravi čas“ jer je upravo u to vreme izrađivan i delimično sprovođen $u$ delo plan izgradnje novih instituta Akademije nauka SSSR, pa će „dobar deo materijala za nas naručiti oni $u$ Nemačkoj uz svoje porudžbine“", ocenio je Savić. ${ }^{12}$

Cela ideja osnivanja Instituta se zasnivala na svesrdnoj pomoći i poverenju akademika Pjotra Leonidoviča Kapice koje je Savić uspeo da zadobije tokom boravka u Moskvi. „Mi u Kapici imamo čoveka koji nas u tome može pomoći više nego ma ko drugi, a on to i želi od sveg srca“, zaključio je Savić. Kapica je izrazio želju da u septembru poseti Jugoslaviju i naročito da se upozna sa Titom, što je Savić podržavao rečima: „poznavajući silu kojom Ti osvajaš ljude, siguran sam da bi se on posle tog susreta sav založio za našu stvar“. Dodao je: „Ako bi ga Ti pozvao, on bi se s najvećom radošću tome odazvao, jer je više puta sam to izjavio. Postoji bojazan da ga ne bi sovjetska vlada pustila, jer im je neophodan. Ako i najmanja mogućnost za to postoji, onda će to učiniti samo na Tvoj poziv“. ${ }^{13}$

Slične stavove i očekivanja je već izneo i Kapica u svom pismu Titu od 13. marta 1946. ističući da su on i njegovi saradnici voljni da pruže svakovrsnu pomoć u razvoju jugoslovenske nauke. Razloge za to je nalazio ne toliko u „vekovnim simpatijama između ruskog i srpskog naroda“, već u „iskrenim simpatijama prema herojskim naporima jugoslovenskog naroda $\mathrm{u}$ borbi za nezavisnost i slobodu i stremljenju ka izgradnji pravednih demokratskih društvenih odnosa". U razgovorima sa Pavlom Savićem kako bi se ta pomoć najbolje mogla realizovati zaključeno je da treba omogućiti mladim jugoslovenskim naučnicima da se bave naučnim radom u sovjetskim naučnim ustanovama (kako je to upravo Savić činio), omogućiti talentovanim mladim Jugoslovenima da steknu visoko obrazovanje u Moskvi, Lenjingradu i drugim sovjetskim visokim školama, i na kraju, pomoći u projektovanju, organizovanju i snabdevanju naučnom opremom Fizičkog instituta u Beogradu. Zajedno sa Savićem i saradnicima je izrađen preliminaran plan za realizaciju tih mera koji je trebalo dati na odobrenje i koji je bio takvog obima i karaktera da je bilo nužno dati mu zvaničnu formu. Kapica je izražavao uverenje da je to Tito mogao lako ostvariti s obzirom na „prijateljski i blagonaklon“ odnos Staljina i celog sovjetskog naroda prema Jugoslaviji

${ }^{12}$ AJ, KMJ 836, II-6-a/2, Pismo Pavla Savića o stvaranju Fizičkog instituta u Beogradu, 17. mart 1946.

${ }^{13}$ Isto. 
i obećavao da će učiniti sve što je u njegovoj moći da bi se pomoglo razvoju nauke u Jugoslaviji i njenoj tesnoj saradnji sa sovjetskom naukom. Tom cilju je znatno doprinosio i Savićev boravak u Moskvi kojim su Kapica i njegovi saradnici bili vrlo zadovoljni. ${ }^{14}$

Uz pisma Savića i Kapice Titu priložen je detaljan „Projekat izgradnje Fizičkog instituta u Beogradu“, na srpskom i ruskom jeziku, u kojem je razrađeno šta je potrebno da bi se Institut izgradio, koji materijal se mogao nabaviti ili izraditi u SSSR-u, kad i kako bi jugoslovenski studenti, naučnici i tehničari dolazili na studije i specijalizaciju u SSSR i koje korake je jugoslovenska vlada trebalo da učini kod sovjetske vlade da bi predloženi plan bio zvanično odobren i realizovan. Na početku je u obrazloženju projekta objašnjeno i zašto je za takav poduhvat tražena pomoć od Sovjetskog Saveza: „Stanje u kome se nalaze naše ustanove za visoko stručno obrazovanje i kadar učenika koji iz njih izlaze nije ni pre rata, odgovarao postavljenom zadatku i potrebama zemlje. Posle ovoga rata kada je većina univerzitetskih laboratorija i instituta, kao i drugih viših stručnih ustanova, potpuno uništena od strane neprijatelja, kada su kadrovi stručnjaka, naročito univerzitetskih nastavnika osetno proređeni i ostali bez podmlatka, to se stanje još mnogostruko pogoršalo. Mi danas u čitavoj zemlji nemamo ni jedan kompletan fakultet za prirodne i primenjene nauke, ni jednu potpunu stručnu biblioteku. Sadanja generacija studenata, koja treba da otpočne svoje stručno obrazovanje, nema ne samo gde i čime, no u većini slučajeva ni kod koga da uči. Nivo naše nauke i nastave daleko je zaostao iza savremenog. Da izađemo iz takvog stanja možemo jedino pomoću sa strane, a gotovost sovjetskih ljudi da nas pomognu i mogućnost da to učine predstavlja za nas $\mathrm{u}$ isti mah i najsrećnije i jedino moguće rešenje" ${ }^{15}$

Prema projektu, trebalo je da najdalje do proleća 1947. u Jugoslaviji počne zidanje odgovarajuće zgrade za Institut, koja je imala specifične uslove, te je po Kapicinoj preporuci jedan jugoslovenski arhitekta trebalo da dođe u SSSR gde bi se upoznao sa tim poslom prateći izgradnju instituta i fakulteta koju je preduzimala sovjetska vlada. Savić je sugerisao da Toni (Antun) Augustinčić zna sposobne arhitekte te bi sa Titovim ovlašćenjem mogao da organizuje taj posao. Mesto za izgradnju je trebalo izabrati i samu izgradnju vršiti u skladu sa planovima za buduće širenje i stvaranje čitavog kompleksa naučno-istraživačkih ustanova. U početku je Fizički institut imao zadatak da razvije istraživačku delatnost i pruži mogućnost specijalizacije jugoslovenskih stručnjaka u sledećim oblastima fizike: 1) fizički problemi niskih temperatura; 2) Rentgenovi zraci i fizika čvrstog

${ }^{14}$ AJ, KMJ 836, II-6-a/2, Pismo Pjotra Kapice Maršalu Josipu Brozu Titu 13. marta 1946.

15 AJ, KMJ 836, II-6-a/2, Projekat izgradnje Fizičkog instituta u Beogradu, 17. marta 1946. 
tela; 3) fizička optika; 4) radiofizika; 5) elektronika; 6) kosmički zraci i fizika atomskog jezgra; i 7) radiohemija. Osnovni pravac rada u Institutu u toku prvih godina trebalo je da bude ispitivanje niskih temperatura, dok je razvoj ostalih navedenih oblasti trebalo da usledi postepeno, a uslove za taj razvoj je trebalo obezbediti odmah izgradnjom određenih objekata i laboratorija. Bila je predviđena izgradnja objekata ukupne površine $3.850 \mathrm{~m}^{2}$ (dva sprata i suteren), sa velikom laboratorijom od $660 \mathrm{~m}^{2}$, bibliotekom, mehaničkom, stolarskom, stakloduvačkom, instrumentalnom, optičkom, monterskom i konstruktorskom radionicom, fotografskom komorom, ostavama za instrumente i materijal, salom za sastanke, amfiteatrom za predavanja, itd. Detaljno je naveden i opšti materijal (podcentrala, akumulatorne baterije, pet motor-generatora različite snage, živini ispravljači za punjenje baterija, generator visoke frekvencije, kompresor, elektromagnet, itd.), materijal za radionice (od struga i tezgi do duvaljki za staklo, oscilografa, ampermetara, voltmetara, potenciometara, itd.), oprema za laboratorije (vakuumne pumpe, aparati za rentgensku analizu, spektrografi, mikroskopi, monohromatori, komparatori, centrifuge, itd.) i različiti instrumenti i pribori (reostati, stabilizatori, ispravljači, elektrometri, otpornici, kondenzatori, razne peći, vage, lampe, itd.). ${ }^{16}$

Projekat je predviđao i školovanje i specijalizaciju stručnih kadrova potrebnih za rad Instituta. Jugoslovenska vlada je trebalo da uputi u SSSR na studije i specijalizaciju određen broj studenata i mladih diplomiranih studenata po određenim naučnim disciplinama, i to prvu grupu od 4 studenta raznih semestara fizike i matematike i 2 diplomirana fizičara tokom juna-jula 1946; drugu grupu od 4 studenta, 2 diplomirana fizičara i 2 majstora mehaničara u martu 1947; i treću grupu od 8 studenata i 2 mehaničara juna 1947. Njihovo izdržavanje za vreme studija i specijalizacije trebalo je da snosi jugoslovenska država. Procenjivano je da za planirani početak rada Fizičkog instituta 1949. godine treba obezbediti 19 stalnih i 27 nestalnih stručnjaka za laboratorije: za niske temperature ( 4 stalna i 5 nestalna), Rentgenove zrake $(2+3)$, fizičku optiku $(2+3)$, radiofiziku (2+3), elektroni$\mathrm{ku}(2+3)$, kosmičke zrake $(5+7)$ i radiohemiju $(2+3)$. Pri tome, smatrano je da se u zemlji može naći 12 stručnjaka koji bi posle planirane specijalizacije u SSSR-u mogli da obavljaju povereni posao, dok je 7 stručnjaka, pretežno rukovodilaca, trebalo pozvati iz inostranstva (2 za niske temperature; 1 rukovodilac za Rentgenove zrake; 1 rukovodilac za fizičku optiku; 1 rukovodilac za elektroniku; 2 rukovodioca za kosmičke zrake). Trebalo je obezbediti i pomoćno osoblje za radionice, 38 majstora i 12 učenika: 12 mehaničara i 4 učenika za mehaničku radionicu; 2 stolara; 2 majstora duvača stakla i

${ }^{16}$ Isto. 
2 učenika; 2 majstora za instrumente i 2 učenika; 2 majstora za optiku i 2 učenika; 4 elektromontera; 7 laboranata; 2 konstruktora; 3 mehaničara i 1 učenika za niske temperature; 2 mehaničara i 1 učenika za kompresorno odeljenje. Predlagano je da spremanje kadrova bude izvršeno u Institutu za fizičke probleme Akademije nauka SSSR (direktor akademik P. L. Kapica) za oblast niskih temperatura; u Fizičkom institutu Akademije nauka SSSR (direktor akademik S. I. Vavilov) za oblast fizičke optike i radiofizike; u Lenjingradskom fizičko-tehničkom institutu Akademije nauka SSSR (direktor akademik J. J. Jofe) za oblast rentgenskih zrakova, fizike čvrstog tela i elektroniku; $u$ institutu akademika A. I. Alihanova za oblast kosmičkih zrakova, fizike atomskog jezgra i radiohemije, i u drugim sovjetskim naučnim ustanovama kao što su Moskovski državni univerzitet, Lenjingradski državni univerzitet i Viša fiziko-tehnička škola u Moskvi. ${ }^{17}$

Predlozi izneti u projektu bili su rezultat dogovora Pavla Savića i sovjetskih naučnika, pre svega akademika Kapice. Međutim, da bi se realizovala pomoć koju su bili spremni da pruže sovjetski naučnici bilo je potrebno da jugoslovenska vlada preduzme izvesne korake kod vlade SSSR-a, odnosno da „zamoli“ vladu SSSR za odobrenje da se u sovjetskim fabrikama i zavodima izradi traženi materijal; da se prilikom sklapanja novog trgovinskog ugovora Jugoslavije i SSSR-a obuhvati izvršenje te nabavke i predvidi suma i način isplate kao i obaveza da ona bude na vreme izvršena; i da zamoli vladu SSSR-a da dopusti školovanje naših studenata i specijalizaciju već diplomiranih studenata naših škola u sovjetskim institutima, radi pripreme neophodnog kadra projektovanog Instituta. Savić i Kapica su u pismima predlagali Titu da tokom predstojeće posete Moskvi zamoli Staljina za potrebna odobrenja i pomoć, pri čemu je ruski primerak Projekta mogao da posluži kao već spremljen materijal za novi trgovinski ugovor, koji je trebalo da sklope Jugoslavija i SSSR. Po dobijanju traženog odobrenja od sovjetske vlade i ukoliko bi se sve mere preduzele na vreme, Projektom je predviđano da Fizički institut počne sa radom leta 1949. godine. ${ }^{18}$

Treba istaći i da je Savić na osnivanje Fizičkog instituta gledao iz šire i opštije perspektive od isključive želje da se razvija fizika, ili još uže nuklearna fizika. On je tu aktivnost posmatrao u okviru opštih napora da se $\mathrm{u}$ novoj državi postave organizacioni i institucionalni temelji naučnoistraživačkog rada. Smatrao je da kada se osnuje institut dobiće se neophodna i najmodernija institucija te vrste i osnovni kadar ljudi sa kojima za relativno kratko vreme može mnogo da se uradi. U perspektivi su se otvarale i mogućnosti šire naučne kadrovske politike: „Tada bismo imali gde da

${ }^{17}$ Isto.

${ }^{18}$ AJ, KMJ 836, II-6-a/2, Projekat izgradnje Fizičkog instituta u Beogradu, 17. marta 1946, pismo P. Savića Titu 17. marta 1946. i pismo P. Kapice Titu 13. marta 1946. 
primimo i ljude sa strane, voljne da nas pomognu, a i da prikupimo svoje, koji danas rade za tuđina ([Lavoslav] Ružička, [Vladimir] Prelog, i dr.)... Ja ću se smatrati najsrećnijim, kad naši mladi ljudi, koji se odaju nauci, mogu da se razvijaju kod svoje kuće i rade za svoj narod, jer sam sam iskusio šta znači rad u tuđini i za tuđina".

U tom kontekstu Savić je posmatrao i pomenuto kasnije širenje Instituta. Mesto za izgradnju je trebalo odabrati tako da bude mogućno docnije podizanje novih srodnih instituta, ,jer jedan povlači drugi“, što bi se po dolasku prvih kadrova odvijalo brzo. Institut je trebalo da bude jedinstvena ustanova te vrste u zemlji „,jer samo crpeći sve izvore snaga i brižljivim i dugotrajnim odabiranjem kadrova iz cele zemlje, možemo stvoriti ustanovu te vrste onakvom kakva treba da bude". Predviđeno je da u samom početku Institut sadrži pomoćne laboratorije koje bi bile jezgra budućih samostalnih instituta, među kojima bi sam Fizički institut bio centar mreže institucija koje bi se planski i sračunato razvijale u bliskoj budućnosti, u skladu sa snagama i mogućnostima, a sve u cilju efikasnog razvoja celokupne nauke i tehnike. Savić je išao u širinu, imajući u vidu i „budući Akademski grad - naselje" i obrazovanje jedne državne Akademije nauka, koja bi morala da rukovodi opremanjem kadrova i podiže našu nauku i industriju. Smatrao je da nije preuranjeno da se o tome razmišlja već tada upozoravajući da „nije ništa teže nego ukloniti tvorevine improvizacije i slučajnog rada“. Ta predstojeća, državna, jugoslovenska i jedinstvena za celu zemlju Akademija nauka nije mogla da postane stapanjem već postojećih nacionalnih akademija, jer su se tome protivili mnogi razlozi, čiju opravdanost je pokazivalo i sovjetsko iskustvo. Pisao je Titu: „Mi moramo stvoriti jedan centar za planski naučno-istraživački i konstruktorski rad mimo postojećih ustanova (Akademija u Beogradu, Zagrebu i Ljubljani), kao novo i duhom i snagom i telom, pa dopustiti da u njegovoj senci nađu otičišta [verovatno „stecišta“] oni zdravi elementi, koje još te ustanove sadrže. Bojim se da sve ovo ne izgleda preuranjeno, ali Te uveravam da je svaki detalj izloženog savesno i mnogo puta pretresen pre nego što je napisan“. U ovim redovima se vidi Savićeva vera u revolucionarne ideale i poseban karakter nove države i društva, ali pre svega, da su se sve njegove nade u izgradnju Fizičkog instituta i planiranje razvoja naučnog rada i ustanova u zemlji oslanjale na Tita: „Ako Ti, druže Maršale, položiš temelje našoj nauci, kao što si učinio sa Armijom i Državom, onda smo mi i na tom polju za kratko vreme među najboljima“, zaključio je Savić u pismu Titu. ${ }^{19}$

Prema sopstvenim rečima u pismu Titu, Savić je radu na osnivanju instituta "posvetio sve nade“ i smatrao „svojim životnim delom" u nadi da

${ }^{19}$ AJ, KMJ 836, II-6-a/2, Pismo Pavla Savića o stvaranju Fizičkog instituta u Beogradu, 17. mart 1946. 
će „opravdati do kraja poverenje“. Sem toga, svakodnevno je radio u Institutu kod Kapice na usavršavanju ,jedne metode dobijanja niskih temperatura, koju sam postavio prilikom prvog dolaska ovamo (1944)." Posebno svetlo na Titova interesovanja u to vreme (početak 1946) baca činjenica da mu je Savić uz pismo i projekat za Fizički institut poslao „knjigu Smita 'Atomska energija' koja je podigla toliki šum. Ovde se ona umnožava radi instrukcije stručnjaka, jer sadrži onaj deo rada na tom polju, koji su angloamerikanci izveli za vreme rata i koji nije bio publikovan“. U pitanju je bila knjiga Henry de Wolf Smyth, Atomic Energy for Military Purposes: The Official Report on the Development of the Atomic Bomb under the Auspices of the United States Goverment 1940-1945. A General Acount of the Scientific Research and Technical Development That Went into the Making of Atomic Bombs, Princeton University, 1945, koja je objavljena nekoliko dana posle bacanja atomskih bombi na Hirošimu i Nagasaki avgusta 1945. Za kratko vreme je doživela niz izdanja i prevoda na više svetskih jezika, između ostalog brzo je objavljeno i rusko izdanje Г. Д. Смит, Айомная Энеріия gля военных иелей, Москва 1946, koje je Savić i poslao Titu. Tako je Tito, svega nekoliko meseci posle eksplozija prvih atomskih bombi, imao prilike da se upozna sa dostupnim informacijama o njihovom nastanku i sa najaktuelnijim saznanjima o upotrebi atomske energije u vojne svrhe. ${ }^{20}$

Iz pisma Titu i podnetog projekta, može se zaključiti da je Savić drugi put boravio u Moskvi 1945/46. sa jasnim zadatkom da ispita mogućnosti za osnivanje Fizičkog instituta u Jugoslaviji i da pridobije sovjetske naučnike i državu da u tome pruže pomoć. U tome je i uspeo i izneo je konkretne predloge, ali sama ideja o osnivanju Instituta za fiziku i brzina njenog sprovođenja zavisila je od rukovodilaca dve države i njihovih planova. Kako je i predviđano u planovima Savića i Kapice, Josip Broz Tito je dobio priliku da se direktno upozna sa mogućnostima osnivanja instituta i direktno zatraži pomoć od sovjetske vlade tokom zvanične posete Sovjetskom Savezu od 27. maja do 10. juna 1946. Prema kasnijim kazivanjima Pavla Savića, Tito je tom prilikom posetio i Institut za fizičke probleme u Moskvi i upoznao se i razgovarao sa Kapicom, i tek tada lično izneo ideju o osnivanju Instituta za fiziku u Beogradu, koju su on i Kapica samo prihvatili, prećutkujući prethodnu prepisku sa Titom i sopstvenu ulogu i napore na ispitivanju mogućnosti za osnivanje takve ustanove, dobijanju pomoći od sovjetskih naučnika i kreiranju projekta za osnivanje instituta. Savić se prisećao Titove posete Institutu za fizičke probleme u Moskvi juna 1946: „Tom prilikom dok je Tito obilazio Institut, kaže mi: 'Dođi ti u zemlju da gradimo naš institut'. Tada je u stvari pala odluka o tome“.Međutim, i pored Savićevog svedočenja, tokom ove posete nije bilo pomena o osnivanju Instituta za

${ }^{20}$ Isto. 
fiziku u Beogradu, niti zahteva za pomoć u tome od sovjetskih vlasti, kako su predlagali Savić i Kapica. ${ }^{21}$ U zvaničnim dokumentima se ne pominje ni Titova poseta Institutu za fizičke probleme i razgovor sa Kapicom, tako da, iako su se taj susret i poseta i desili, bili su van zvaničnog dela programa. ${ }^{22}$ U 2. članu Sporazuma o ekonomskoj saradnji potpisanom 8. juna 1946. Vlada SSSR se načelno obavezala da pruži Vladi FNRJ tehničku pomoć u raznim oblastima industrije i poljoprivredi „putem slanja sovjetskih stručnjaka u Jugoslaviju, pružanja tehničkih informacija, razrade projekata i druge tehničke dokumentacije i uputstava, kao i školovanja u SSSR jugoslovenskih stručnjaka i njihovog upoznavanja sa radom preduzeća i naučnotehničkih ustanova SSSR". ${ }^{23}$ Istog dana je sklopljen i Sporazum o uzajamnim isporukama robe između SSSR i FNRJ, a u spisku robe za izvoz iz SSSR u Jugoslaviju pominje se svega nekoliko uređaja koje su Savić i Kapica uneli u projekat za osnivanje Instituta, a koji su svakako mogli da služe i za druge potrebe (ispravljači sa živom, voltmetri, ampermetri, itd.), dok se ogromna većina predviđenog materijala, opreme i instrumenata za Fizički institut ne pominje. ${ }^{24}$ Dakle, i pored uspona odnosa dve države u svim oblastima, svestrane sovjetske pomoći, podrške sovjetskih naučnika razvoju jugoslovenske nauke i ugleda i truda Pavla Savića, još uvek nije bilo mesta za pomoć u izgradnji tako važne naučne ustanove kao što je bio Institut za fiziku.

U prilog tome govori i pismo Pavla Savića Mitri Mitrović, ministarki prosvete NR Srbije, od 16. juna 1946, nekoliko dana po završetku Titove posete Moskvi. Savić je bio obavezan da ministarki pošalje detaljan izveštaj, ali on se žali da izveštaj ne bi bio sadržajniji jer „od svega za šta sam došao ovamo, gotovo ništa do sad nije učinjeno“. Obavestio ju je da je uz pomoć Kapice, Šaljnikova i drugih sovjetskih stručnjaka u toku prva dva meseca

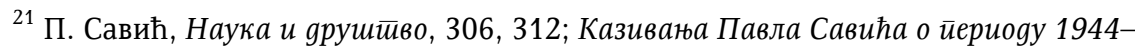
1960, 10; М. Јевтић, н. g., 23; С. Рибникар, Павле Савић (1909-1994), 423; Пола века Инсиичйуйа „Виниа“ (1948-1998), Београд 2000, 13. Po tim naknadnim sećanjima, tek posle Titove posete i odluke da se gradi institut iz juna 1946, Savić, Kapica i sovjetski naučnici su počeli da sastavljaju projekat, spiskove aparature i materijala koje je trebalo tražiti od sovjetske države.

${ }^{22}$ AJ, KMJ, I-1/7, Put Josipa Broza Tita u SSSR, 27. V - 10. VI 1946; Јуі̄ословенскосовјешиски ояноси 1945-1956, Зборник докумената, Београд 2010, 105-124; Јуїославија СССР. Сусретии и разіовори на највишем нивоу руководилаи, Јуїославије и СССР 19461964, Том 1, Београд 2014, 51-54. Tokom razgovora dveju delegacija bilo je reči o ekonomskoj pomoći, trgovini, osnivanju mešovitih društava, vojnoj pomoći, međunarodnim pitanjima, Trstu, Albaniji, Bugarskoj, itd.

${ }^{23}$ Сйоразум о економској сараяњи између СССР и ФНРЈ, 8. јип 1946, Југословенско-совјетски односи 1945-1956, 119-122.

${ }^{24}$ AJ, fond Predsedništvo Vlade FNRJ, 50-64-139, Sporazum između Vlade SSSR i Vlade FNRJ o uzajamnim isporukama robe i Spisak robe za izvoz iz SSSR u Jugoslaviju, 8. jun 1946. 
proučavao „čisto tehničku stranu pitanja osnivanja Fizičkog instituta kod nas“, da je izradio Projekat osnivanja Instituta i uputio ga Titu sa detaljnim potrebama koje je trebalo uneti u petogodišnji plan rada Akademije nauka SSSR i u Trgovinski ugovor Jugoslavije i SSSR. Međutim, onda joj se požalio da uprkos potrebi da se požuri, nije dobio nikakav odgovor od maršala Tita. Isticao je da izradu materijala i specijalizaciju jugoslovenskih kadrova mora formalno da odobri sovjetska Vlada i da je spisak ljudi koje je trebalo uputiti na specijalizaciju predao Veljku Vlahoviću još prilikom polaska u Moskvu (jer je ona bila u Parizu). Naglasio je da prva grupa treba da dođe već u julu 1946. i da treba što pre naći mesto i početi izgradnju zgrade kako bi bila završena kad stignu prve isporuke instrumenata. Sa obraćanjem sovjetskoj vladi je trebalo požuriti i da bi navedene potrebe ušle u sovjetski petogodišnji plan, ,jer posle nam ne mogu ništa pomoći, kad plan njihove Akademije bude primljen". Potom je dao i nekoliko opštih obaveštenja: da se u Sovjetskom Savezu sprema "velika izdavačka delatnost" i da će uskoro biti mnogo lakše nabavljati knjige za jugoslovenske škole; da o slanju astronoma ne može biti ni reči jer u njima najviše oskudevaju; i da bi drugi stručnjaci rado došli u Jugoslaviju, ako bi imali gde da rade da ne bi gubili vreme. Na kraju je prilično ogorčeno zaključivao: „Ja sem staranja da steknemo pomenuti Institut i nekog uzgrednog posla na niskim temperaturama, nemam nikakvo drugo zanimanje, koje bi pravdalo moj ovdašnji boravak, ako se iz bilo kog razloga, ne može da ostvari osnivanje Fizičkog Instituta kod nas. Ovo smatram, draga Mitro, za najvažnije od svega, što sam imao da ti javim. Bojim se da, bilo ti, bilo ko od drugova, nemate uverenje da se čime drugim, važnijim bavim, pa da ne budete u zabludi, smatram za potrebno da to naglasim. Ispalo je da sam i ovde stranac. " 25 Očigledno da Savićeva žurba i entuzijazam nisu davali rezultate koje je očekivao i da osnivanje Instituta nije moglo ići brzinom koju je želeo.

Savić se krajem 1946. vratio u zemlju i preuzeo brojne dužnosti u Partiji, na Beogradskom univerzitetu i Srpskoj akademiji nauka. Još septembra 1945. bio je izabran za redovnog profesora fizičke hemije na Filozofskom fakultetu u Beogradu, a potom 1947. za profesora i upravnika fizičko-hemijskog zavoda na Prirodno-matematičkom fakultetu u Beogradu. U međuvremenu je obavljao i dužnost prorektora Beogradskog univerziteta, a marta 1946. postao je i dopisni član Srpske akademije nauka. ${ }^{26}$

${ }^{25}$ AJ, CK SKJ, 507, Ideološka komisija, VIII, IV/d,-3-73, Pavle Savić - Mitri Mitrović, 16. jun 1946. Savić i u pismu Titu 17. marta 1946. pominje spisak ljudi koje je sa Titovom dozvolom našao u Beogradu, Zagrebu i Ljubljani i predao pred dolazak u Moskvu Veljku Vlahoviću, kao predlog za specijalizaciju u SSSR-u.

${ }^{26}$ AS, MPS, fasc. III, dosije 26 (dosije P. Savića); Arhiv SANU, Dosije Pavla Savića; П. Савић, Наука и друшишво, 281-283; Казивања Павла Савића о иеериоgу 1944-1960, 10. 
Ipak, najvažniji zadatak kojem je bio posvećen od jeseni 1947. godine bio je izgradnja Instituta za fiziku u Vinči. Pri tom mu je svakako od velike pomoći bilo iskustvo stečeno tokom boravka u Moskvi 1944. i 1945/46. i projekat koji je tamo nastao. Međutim, direktne materijalne i kadrovske pomoći sa sovjetske strane nije moglo biti, pošto je već počinjao dubok raskol i prekid svih odnosa između državnih i partijskih rukovodstava Jugoslavije i Sovjetskog Saveza.

\section{Dragomir Bondžić}

\section{PAVLE SAVIĆ'S WORK IN MOSCOW 1944 AND 1945/46 AND PROJECT FOR CONSTRUCTION OF THE YUGOSLAV INSTITUTE OF PHYSICS}

\section{Summary}

Pavle Savić, distinguished Serbian scientist, Communist and Partisan, was twice in Moscow since 1944 to 1946: since April to October 1944, and since July 1945 to autumn 1946. Both times he dealt with scientific research in the Institute of physical problems, but during his second staying he paid special attention on providing funds, and financial and personnel assistance for the establishment of the Institute of Physics in Yugoslavia. Together with Soviet scientists led by academician Pyotr Leonidovich Kapitsa, Savić has compiled a detailed project for construction of institute of Physics, and predicted that necessary professional staff should be trained, and necessary material, instruments and apparatus should be purchased in Soviet Union. The project and plans were presented to Josip Broz Tito, and it was proposed to him to formally request help of Soviet government in realization of project, during his visit to Moscow in June 1946. In later memoirs it is mentioned that Tito was first to put forward the idea of building the institute of Physics in Yugoslavia during his visit to Moscow. But, the archival sources clearly indicates that Pavle Savić went to Moscow with a clear assignment to examine possibilities, to design the project and to win support for the construction of the institute. In autumn 1946 Savić came back to Belgrade, and since autumn 1947 he worked intensively on building of Institute of Physics in Vinča, but without the assistance of the Soviet Union, with which the Yugoslav leadership was on the threshold of bitter conflict. 